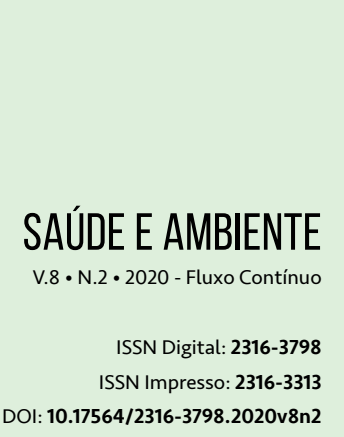

DOI: $10.17564 / 2316-3798.2020 v 8 n 2$
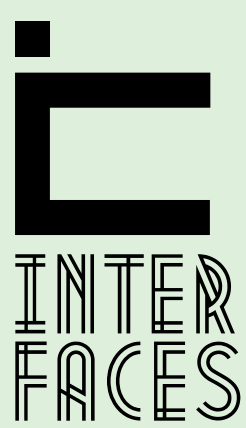

CIENTÍFICAS

\title{
EFFECTIVENESS OF FORMOL AND AMMONIA ON DISINFECTION OF CHICKEN BED
}

\section{EFICÁCIA DO FORMOL E DA AMÔNIA NA DESINFECÇÃO DE CAMA DE GALINHA}

\section{EFICACIA DE FORMOL Y AMONIACOENLA DESINFECCIÓN DE CAMA DE POLLO}

Jaquiel Bampi

Monica Cuppini Bampi Antonio Mataresio Antonucci ${ }^{3}$

\section{ABSTRACT}

The Brazilian poultry industry is one of the largest in the world, and the country is the world's largest chicken exporter. With this, there is an increase in the amount of aviaries and their density, also increasing the number of pathogens and diseases. In this sense, it is of fundamental importance the use of efficient disinfectants against the different pathogens that cause diseases and negatively impact the production and the quality of the final product. The objective of this study was to compare the antibacterial activity between commercial disinfectants (quaternary ammonia and formaldehyde) against Salmonella sp. and Escherichia coli, in the presence of organic matter (aviary litter). Statistica 5.0 software was used to analyze the experimental data, adopting a confidence level of $95 \%$ $(p<0.05)$ in the Tukey test. There was a significant difference between the two disinfectants tested, with formaldehyde being more effective than ammonia against Salmonella sp. There was no significant difference between the two disinfectants tested against E. coli. However, there was a significant difference between the tested products and the control treatment, showing that the two products had an effect on the reduction of the two microorganisms tested in the presence of organic matter. It is understood that more studies are needed to evaluate more variables like time and concentration of formaldehyde that in this study presented better effectiveness in chicken litter.

\section{KEYWORDS}

Disinfection. Escherichia Coli. Organic Matter. Salmonella sp. 


\section{RESUMO}

A indústria avícola brasileira é uma das maiores do mundo e o país é o maior exportador mundial de frango. Com isso, há um aumento na quantidade de aviários e sua densidade, aumentando também o número de patógenos e doenças. Nesse sentido, é de fundamental importância o uso de desinfetantes eficientes contra os diferentes patógenos que causam doenças e impactam negativamente a produção e a qualidade do produto final. 0 objetivo deste estudo foi comparar a atividade antibacteriana entre desinfetantes comerciais (amônia quaternária e formaldeído) contra Salmonella sp. e Escherichia coli, na presença de matéria orgânica (cama de aviário). 0 software Statistica 5.0 foi utilizado para analisar os dados experimentais, adotando-se um nível de confiança de $95 \%(p<0,05)$ no teste de Tukey. Houve uma diferença significativa entre os dois desinfetantes testados, sendo o formaldeído mais eficaz que a amônia contra Salmonella sp. Não houve diferença significativa entre os dois desinfetantes testados contra E. coli. No entanto, houve uma diferença significativa entre os produtos testados e o tratamento controle, mostrando que os dois produtos tiveram efeito na redução dos dois microorganismos testados na presença de matéria orgânica. Entende-se que são necessários mais estudos para avaliar mais variáveis, como tempo e concentração de formaldeído, que neste estudo apresentaram melhor efetividade em serapilheira.

\section{PALAVRAS-CHAVE}

Desinfecção; Escherichia coli; matéria orgânica; Salmonella sp.

\section{RESUMEN}

La industria avícola brasileña es una de las más grandes del mundo, y el país es el mayor exportador mundial de pollos. Con esto, hay un aumento en la cantidad de aviarios y su densidad, lo que también aumenta el número de patógenos y enfermedades. En este sentido, es de fundamental importancia el uso de desinfectantes eficientes contra los diferentes patógenos que causan enfermedades e impactan negativamente en la producción y la calidad del producto final. El objetivo de este estudio fue comparar la actividad antibacteriana entre desinfectantes comerciales (amoníaco cuaternario y formaldehído) contra Salmonella sp. y Escherichia coli, en presencia de materia orgánica (pajarera). Se utilizó el software Statistica 5.0 para analizar los datos experimentales, adoptando un nivel de confianza del $95 \%(p<0.05)$ en la prueba de Tukey. Hubo una diferencia significativa entre los dos desinfectantes probados, siendo el formaldehído más efectivo que el amoníaco contra Salmonella sp. No hubo diferencias significativas entre los dos desinfectantes probados contra E. coli. Sin embargo, hubo una diferencia significativa entre los productos probados y el tratamiento de control, lo 
que demuestra que los dos productos tuvieron un efecto en la reducción de los dos microorganismos probados en presencia de materia orgánica. Se entiende que se necesitan más estudios para evaluar más variables como el tiempo y la concentración de formaldehído que en este estudio presentaron una mejor efectividad en la arena para pollos.

\section{PALABRAS CLAVE}

Desinfección. Escherichia coli. Materia orgánica. Salmonella sp.

\section{INTRODUCTION}

The Brazilian poultry industry is among the largest economic powers in agriculture and livestock, registering growth in the production of poultry and byproducts. This is due to the increase in the consumption of poultry products in several countries, as well as the improvement of the genetics, health, nutrition and zootechnical management sectors (PINTO; LECZNIESKI, 2007).

Currently poultry production is only feasible through the development of programs for the promotion and maintenance of poultry. In order to do so, the companies have developed biosecurity programs, in which one of the main steps is the disinfection of the facilities, capable of destroying pathogenic microorganisms for birds (BERMUDEZ; STEWART-BROWN, 2003).

Intensive breeding systems determine high animal density. In certain areas geographically favorable to the maintenance of chickens, the concentration of intensive breeding is high, forming an environment conducive to multiplication, dissemination and perpetuation of several pathogens. The occurrence of illnesses entails high losses to the sector and its dependent society. Effective biosecurity programs are the only way to keep production systems controlled, free from the presence of pathogens with economic impact and public health risk, as they are measures provided for in the National Poultry Health Program (PNSA) (SESTI, 2004).

Prophylactic measures used in animal health, such as population density reduction, single-age farms, well-prepared vaccination programs, vehicle flow control, access to facilities and cleaning and disinfection of poultry can be applied to chicken production (BORDIN et al., 2005). Among the measures applicable to the production of chickens, cleaning and disinfection of the sheds and the sanitary void between lots are extremely efficient in reducing environmental contamination and the challenges precocious by infectious agents, optimizing the zootechnical result of the lots (FERREIRA; KNÖBL, 2009).

Technical measures such as the routine cleaning and disinfection of the premises have been part of the aviculture technified for decades. The removal of debris and elimination of agents causing diseases such as viruses, bacteria and parasites, before housing a new batch of animals, remains an important step (RISTOW, 2008). 
Pathogenic microorganisms can be introduced into a poultry farm or hatchery in various ways as introduction of infected fertile eggs and reuse of bed of chicken (JARDIM, 2015). For this reason, cleaning and disinfection protocols are essential components of any biosafety program. And, when correctly adopted, they may be a mean of reducing pathogenic microorganisms and become essential for modern poultry farming, both on the farm and in the hatchery (GREZZI, 2007; SESTI, 2004).

According to Berchieri Junior and collaborators (2009), the hygiene and environmental prophylaxis measures of the poultry facility represent an essential aspect of the economy and allow food safety, while preventing the spread of outbreaks of exotic diseases.

The mechanism of action of formaldehyde even when used in low concentrations produces accumulation of the 1,3-thiazine-4-carboxylic acid, an inhibitor of the formation of the amino acid methionine, or exerts direct toxic action on the cells. While the concentrations are getting higher, formaldehyde precipitates proteins (PAULINO, 2006).

Still according to Paulino (2006), the ammonium compounds cause denaturation and precipitation of the cell membrane proteins and of the bacterial cytoplasm, releasing nitrogen and potassium from the cells. They also act by breaking down the lipoprotein complexes of the bacterial cell by releasing autolytic enzymes. In general, it combines with proteins, lipids and some phosphates and has high adsorption power in the cell wall, where they exert their antibacterial action.

The selection of the disinfectant to be used should prioritize a broad-spectrum product, as well as compliance with legal and safety requirements. It is also essential to consider the surface to be disinfected, amount of organic matter, temperature, amount of water, contact time, activity spectrum, residual power, as well as to evaluate the cost benefit for the use of each product (BORDIN et al. 2005; KUANA, 2009).

In this sense, the objective of this study was to compare the antibacterial activity between two commercial disinfectants (formalin $37 \%$ and quaternary ammonia $12.5 \%$ ) against two contamination indicators Salmonella spp. and Escherichia coli, commonly present in chicken bed.

\section{MATERIAL AND METHODS}

The present experiment was conducted in the months of June 2017 under the approval of the Ethics Committee on Animal Experimentation of UNINGA with registration PM $12 \backslash 2017$, at the Laboratory of Pathology and Bromatology of the Aurora Food Center in Xaxim, SC. The following products were tested against E. coli and Salmonella spp.: Formol $37 \%$ and $12.5 \%$ quaternary ammonia. The substrate used was aviary bed from a commercial plot created in the municipality of Mandaguarí, PR. This substrate was collected with the aid of shovel and plastic bag after leaving the poultry lot and sent to Aurora Central Laboratory. The chicken bed was divided into two trays $(0.27 \mathrm{~m} 2)$ with $300 \mathrm{~g}$ each, for each product tested, so a total $1,200 \mathrm{~g}$ the chicken bed collected. Each tray was sterilized in autoclave at $120^{\circ} \mathrm{C}$ for 30 minutes.

After being sterilized, in the first tray of the challenge was performed by spray on the bed surface, with $50 \mathrm{~mL}$ of Salmonella spp. in the concentration of $108 \mathrm{CFU} / \mathrm{mL}$, in the second tray the challenge was performed by spray with $50 \mathrm{~mL}$ of $\mathrm{E}$. coli at $108 \mathrm{CFU} / \mathrm{mL}$. 
After two hours of contact, each tray was divided into three equal parts and one sample from each tray was considered a control, while the other two samples from each tray were submitted to $37 \%$ formalin (4\% dilution) and ammonia (dilution 1: 200). Three control samples and three more samples of each treatment were collected, totaling nine samples for each bacterium.

After two hours of exposure to disinfectants, 25 grams of each treatment was collected and diluted in $0.1 \%$ saline solution.

For E. coli counts, $1 \mathrm{ml}$ of the dilutions were seeded by the Pour Plate technique on sterile plates on VRBG agar layer. The plates were incubated at $36 \pm 1^{\circ} \mathrm{C}$ for 24 hours.

For the counting procedure of Salmonella spp. $0.1 \mathrm{ml}$ of the dilutions were seeded with Drigalski's handle on bright green agar (plus nalidixic acid and novobiocin) and incubated at $36 \pm 1^{\circ} \mathrm{C}$ for 24 hours.

After 36 hours of incubation, plaque readings and colonies counts were performed. The colonies suspected of Salmonella sp. were selected for biochemical and serological confirmation.

The UFC counts found in the study were reduced in base 10 logarithm for better visualization of the data. Statistica 5.0 software (Statsoft Inc., USA) was used to aid in the statistical elaboration and analysis of experimental data. The mean, standard deviation and the Tukey's test were calculated, adopting a 95\% confidence level $(p<0.05)$ in all the cases studied.

\section{RESULTS}

The results obtained in the counting of the treatment performed in bed of avian contaminated with Salmonella spp. are shown in Table 1.

Table 1 - Mean and standard deviation of treatments performed on bed of avian contaminated with Salmonella spp, results are expressed in Log UFC / g

\begin{tabular}{ccccc}
\hline Treatment & T1 & T2 & T3 & Mean* \\
\hline Control & 3,7 & 3,6 & 4,4 & $3,9 \mathrm{a} \pm 0,44$ \\
Formol 37\% & 3,5 & 2,0 & 2,1 & $2,5 \mathrm{c} \pm 0,84$ \\
Ammonia 12,5\% & 4,1 & 3,4 & 3,5 & $3,6 \mathrm{~b} \pm 0,38$ \\
\hline
\end{tabular}

*Mean and standard deviation followed by equal letters in the column indicate that there is no significant difference at the $5 \%$ level (Tukey's test).

Source: Research data

The results obtained in counting the treatment performed in bed of avian contaminated with $E$. coliare represented in Table 2. 
Table 2 - Mean and standard deviation of treatments performed on litter of E. coli contaminated poultry, results are expressed in Log UFC / g

\begin{tabular}{ccccc}
\hline Treatment & T1 & T2 & T3 & Mean \\
\hline Control & 4,6 & 4,7 & 4,3 & $4,5 \mathrm{a} \pm 0,25$ \\
Formol 37\% & 4,0 & 4,0 & 4,1 & $4,0 \mathrm{~b} \pm 0,05$ \\
Ammonia 12,5\% & 4,4 & 4,1 & 4,6 & $4,3 \mathrm{~b} \pm 0,21$ \\
\hline
\end{tabular}

*Mean and standard deviation followed by equal letters in the column indicate that there is no significant difference at the $5 \%$ level (Tukey's test).

Source: Research data

\section{DISCUSSION}

The Table 1 shows that the most effective disinfectant in the presence of organic matter was formaldehyde. It had a satisfactory result against Salmonella spp. The formaldehyde presented reduction of $1.4 \mathrm{log}$ in relation to the control group. While the disinfectant based on quaternary ammonia presented reduction of $0.9 \mathrm{log}$, a result that differs from Borowsky and collaborators (2006), who found satisfactory results using quaternary ammonium disinfectant on 96 samples of Salmonella sp. (without the presence of organic matter). These results indicate that the presence of organic matter increases the permanence and non-elimination of this microorganism. According to Cony and Zocche (2004) the quaternary ammonia has limited performance in the presence of organic matter and in surfaces with remains of anionic detergents and soaps.

In the study by Sander and collaborators (2002), 17 bacterial groups Staphylococcus, Enterococcus, Salmonella sp, Pseudomonas, Proteus, Escherichia and Pasteurella, isolated in poultry environment, were confronted with three groups of disinfectants: phenolic compounds, quaternary ammonia and hydrogen peroxide. In the case of Salmonella sp., disinfectants from the phenols group inhibited most of the samples, whereas the quaternary ammonia group was unable to promote the inactivation of the same samples. Scur and collaborators (2014) verified that the quaternary ammonia presented the highest CFC counts, showing the lowest efficacy in the control of S. enteritidis, when compared to the other disinfectants in the presence of organic matter.

These results are similar to those found by Cardoso and collaborators (2008), in the sensitivity tests of S. enteritidis against disinfectants based on glutaraldehyde, iodine and quaternary ammonia, observed a 95\% reduction in the CFU counts of $S$. enteritidis for iodine and glutaraldehyde disinfectants while the disinfectant based on quaternary ammonia showed low efficiency in salmonella control. Leite (2002) also reported the low efficiency of the disinfectant as the basis of quaternary ammonia in the control of salmonellae. These results are consistent with those of the present study, since ammonia proved to be less effective than formaldehyde in the inactivation of Salmonella sp. on 
chicken bed. Quaternary ammonia is rapidly inhibited by hard water, fibrous materials and residues of soaps and anionic detergents, as well as organic matter (KUANA, 2009).

Some disinfectants are more effective than others in the presence of organic matter. This fact is justified by Favero and Bond (1991) who reported that organic matter can protect / prevent microorganisms from the necessary contact with the disinfectant and even inactivate the action of some products.

Regarding breeding, the requirements of Normative Instruction no 20 published by the Ministry of Agriculture of Brazil (MAPA) in 2016 (BRASIL, 2016), are applicable to commercial chicken and turkey poultry establishments. Aiming at the control of Salmonella sp, in these establishments all the lots are submitted to sample collections for the accomplishment of laboratory tests. Regarding slaughterers, the measures provided for are applicable only to slaughterhouses registered with the Federal Inspection Service (SIF).

They should establish control and monitoring actions of Salmonella sp. from the raw material (live bird) to the final product (BRASIL, 2016) in their self-control programs. In this sense, none of the products tested resulted in the total absence of Salmonella sp. as required by current legislation, showing that it is necessary to combine a good disinfectant with biosafety practices for better results. According to Bermudez and Stewart-Brown (2003) the implementation of biosafety procedures guarantees the success of poultry production. One of the main steps is the disinfection of the facilities, chemical products must be used in concentrations capable of destroying the pathogenic microorganisms.

Table 2 shows that there was no significant difference between the two disinfectants tested. However, both influenced the reduction of E. coli in relation to the control group in the presence of chicken litter.

Divergent results from this study were reported by Scur et al. (2014) observed that disinfectants based on ammonia and iodine presented the highest counts in reducing $E$. coli. They concluded that organic acids have better action against this microorganism in the presence of organic matter. Gehan (2009) compared the effectiveness of disinfectants used in poultry, observed that the presence of organic matter, E. coli, P. aeruginosa, S. aureus and Fusarium, were resistant to disinfectant with ammonium compound after 60 minutes of contact. According to Grezzi (2007) in the presence of organic matter, disinfectants based on quaternary ammonia become more sensitive, and have their efficacy reduced.

In birds, E. coli infection is considered secondary to other agents and the manifestation of the disease is extra-intestinal. The colibacillosis is one of the major diseases of modern poultry farming, due to the large economic losses caused worldwide for conditions such as: colisepticemia, peritonitis, pneumonia, pleuropneumonia, aerosaculitis, pericarditis, cellulitis, coligranuloma, chronic respiratory disease, omphalitis, salpingitis, syndrome swollen head, panophtalmia, osteomyelitis, oforitis and synovitis (BERCHIERI JUNIOR et al., 2009). Colibacillosis is one of the main diseases of industrial poultry, due to the great economic losses caused worldwide and is usually related to high condemnation rates of poultry carcasses in slaughterhouses (JOHNSON et al., 2008).

The two products reduced the counts of CFU in relation to the control group of E. coli, being the reduction statistically significant. Considering that $E$. coli is an opportunistic bacterium, and that the emergence of a disease caused by this organism will depend on the immunity of the bird in addition to the environmental conditions, it is not possible to say precisely how much of this pathogen is required 
to cause a disease. However, it is understood that the smaller the quantity the less the chance of an infection, in this sense the two products were efficient.

\section{CONCLUSION}

There was a significant difference between the two disinfectants tested, and the formaldehyde was more efficient than the ammonia against Salmonella sp. Plotting that ammonia has its efficiency decreased in the presence of organic matter against Salmonella sp.

There was no significant difference between the two disinfectants tested against $E$. coli. However, the two products showed a difference in level of significance of $95 \%$ between the tested products and the control treatment, in the reduction of E. coliand Salmonellasp. in the presence of organic matter.

It is understood that more studies are needed to evaluate more variables such as exposure time and formalin concentration, which in this study showed a better efficacy in the presence of chicken litter.

\section{ACKNOWLEDGMENT}

To the University Center Inga (UNINGÁ) and to the Laboratory of Pathology and Bromatology of the Central Cooperative Aurora Food for the support to the development of the research.

\section{REFERENCES}

BERCHIERI JUNIOR A. et al. Doenças das aves. $2^{\text {a }}$ ed. Campinas: FACTA. 2009.

BERMUDEZ A.J; STEWART-BROWN B. Principles of disease prevention: diagnosis and control. In: Saif, Y.M. Diseases of poultry. 11 $1^{\text {th }}$ ed. Arnes: Iowa State University Press. 2003.

BORDIN R.A. et al. Biosseguridade aplicada nas granjas de aves e de suínos. Rev. Ciên. Vet v. 3, n. 3, p. 11-16. 2005.

BOROWSKY, L.M. et al. Sensibilidade e resistência de amostras de Salmonella Typhimurium isoladas de suínos abatidos no Rio Grande do Sul/Brasil frente aos desinfetantes químicos quaternário de amônio e iodofor. Ciên. Rural, v. 36, n. 5, p. 1474-1479, 2006.

BRASIL. Ministério da Agricultura, Pecuária e Abastecimento. Secretaria de Defesa Agropecuária. Instrução Normativa $\mathrm{n}^{\circ}$ 20, de 21 de outubro de 2016. Brasília: MAPA. 2016. Disponível em: https:// 
www.gov.br/agricultura/pt-br/assuntos/inspecao/produtos-animal/controle-de-patogenos/arquivoscontrole-de-patogenos/SalmonellaIN202016Salmonella.pdf. Acessado em: 21 de agosto de 2017

CARDOSO, M.O. et al. In vitro efficiency of desinfectants against Salmonella enteritidis samples isolated from broiler carcasses. Rev. Bras. Cienc. Avic. v.10, n.2, p.139-141, 2008.

CONY, A. V.; ZOCCHE, A. T. Manejo de frango de corte. In: Mendes, A.A. et al. Produção de frangos de corte. Campinas: FACTA. 2004.

FAVERO, M.S.; BOND, W.W. Chemical disinfection of medical and surgical materials. In: Block S.S. (ed.) Disinfection, sterilization, and preservation. 5th ed. Philadelphia: Lippincott Williams \& Wilkins. 2001.

FERREIRA, A.J.P.; KNÖBL, T. Colibacilose. In: Berchieri Junior A. et al. Doenças das aves. $2^{\mathrm{a}}$ ed. Campinas: FACTA. 2009.

GEHAN, Z.M. A new approach to evaluate the hygienic condition of commercial hatcheries. Int. J. Poultry Sci. v.8, n. 11, p.1047-1051, 2009.

GREZZI, G. Limpeza e desinfecção na avicultura. In: Conferência APINCO de ciência e tecnologia 2007. SP. Anais. Campinas, 2007.

JARDIM, A. A urgência da biosseguridade avícola. Agroanalysis. Setembro, p. 45, 2015.

JOHNSON, T.J. et al. Identification of minimal predictors of avian pathogenic Escherichia coli virulence for use as a rapid diagnostic tool. J. Clin. Microbiol. v.46, n.12, p. 3987 - 3996, 2008.

KUANA, S. L. Limpeza e desinfecção de instalações avícolas. In: Berchieri Junior A. et al. Doenças das aves. $2^{\mathrm{a}}$ ed. Campinas: FACTA. 2009.

LEITE, C.R.C. Desinfecção química aplicada na avicultura: concentrações inibitórias mínimas de desinfetantes derivados da amônia quaternária e hipoclorito de sódio sobre Salmonella spp. e Escherichia coli. Acta Sci. Vet. v. 30, n. 1, p. 74 - 75, 2002.

PAULINO, C.A. Antissépticos e desinfetantes. In: Spinosa, H. et al. (org.). Farmacologia aplicada a Medicina Veterinária. $4^{\mathrm{a}}$ ed. Rio de Janeiro: Guanabara Koogan. 2006.

PINTO, J. H. M., LECZNIESKI, J. Ração pré-inicial para aves. Aveworld. v. 9, n. 27, 2007. 
RISTOW, L. E. Desinfetantes e desinfecção em avicultura. Aveworld. v. 10, n. 39, 2008

SANDER J.E. et al. Investigation of resistence of bactéria from comercial poultry sources to comercial disinfectants. Avian Dis. v.46, n. 4, p.997-1000, 2002.

SCUR M.C et al. Atividade antimicrobiana de desinfetantes comerciais frente a micro-organismos patogênicos de importância avícola. Acta Iguazu. v.3, n.3, p. 1-10, 2014.

SESTI, L.C.A. Biosseguridade em granjas de frangos de corte: conceitos e princípios gerais. In: Simpósio Brasil - Sul de Avicultura, 5, 2004, SC. Anais. Chapecó, 2004. 


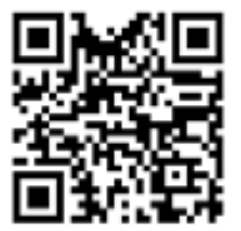

A autenticidade desse artigo pode ser conferida no site https://periodicos. set.edu.br
1 Médico Veterinário, Aurora Alimentos, Mandaguari-PR. E-mail: jaquielbampi@auroraalimentos.com.br

2 Engenheira de Alimentos, Aurora Alimentos, Mandaguari-PR. E-mail: monicabampi@auroraalimentos.com.br

3 Médico Veterinário; Professor - UNINGA.

E-mail: amataresio.antonucci@yahoo.com

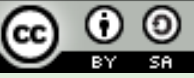

Este artigo é licenciado na modalidade acesso abertosob a Atribuição-Compartilhalgual CC BY-SA

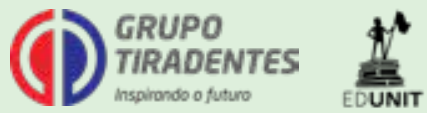

